\title{
Function of cancer cell-derived extracellular matrix in tumor progression
}

\author{
Gao-Feng Xiong ${ }^{1}$, Ren $\mathrm{Xu}^{1,2}$ \\ ${ }^{1}$ Markey Cancer Center, Lexington, KY 40536, USA. \\ ${ }^{2}$ Department of Pharmacology and Nutritional Sciences, University of Kentucky, Lexington, KY 40536, USA.
}

Correspondence to: Dr. Ren Xu, Department of Pharmacology and Nutritional Sciences, University of Kentucky, BBSRB, 741 S. Limestone, Lexington, KY 40536, USA. E-mail: ren.xu2010@uky.edu

How to cite this article: Xiong GF, Xu R. Function of cancer cell-derived extracellular matrix in tumor progression. J Cancer Metasta Treat 2016;2:357-64.

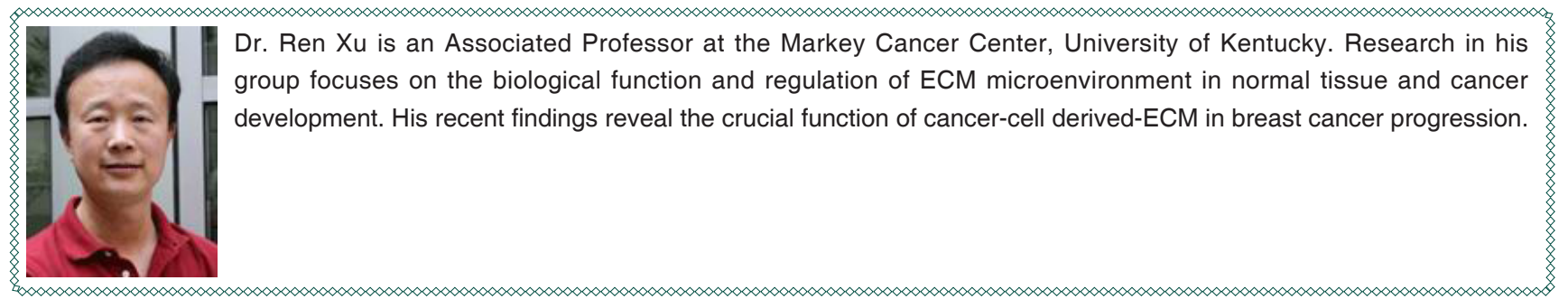

\section{Article history:}

Received: 18-02-2016

Accepted: 06-07-2016

Published: 18-09-2016

Key words:

Tumor microenvironment, extracellular matrix, cancer progression, metastasis

\begin{abstract}
Extracellular matrix (ECM) is an essential component of the tumor microenvironment. Cancer development and progression are associated with increased ECM deposition and crosslink. The chemical and physical signals elicited from ECM are necessary for cancer cell proliferation and invasion. It is well recognized that stromal cells are a major source of ECM proteins. However, recent studies showed that cancer cells are also an active and important component in ECM remodeling. Cancer cells deposit a significant amount of collagen, fibronectin, and tenascin C (TNC). Recent studies demonstrate that these cancer cell-derived ECM proteins enhance cancer cell survival and promote cancer cell colonization at distant sites. ECM-related enzymes and chaperone proteins, such as prolyl-4-hydroxylase, lysyl-hydroxylase, lysyl oxidase, and heat shock protein 47, are also highly expressed in cancer cells. Inhibition of these enzymes significantly reduces cancer growth, invasion, and metastasis. These factors suggest that the cancer cell-derived ECM is crucial for cancer progression and metastasis. Therefore, targeting these ECM proteins and ECM-related enzymes is a potential strategy for cancer treatment.
\end{abstract}




\section{INTRODUCTION}

Cancer development and progression require extensive reorganization of extracellular matrix. ${ }^{[1,2]}$ Extracellular matrix (ECM) is a complex mixture of structural proteins, glycoproteins, and proteoglycans, which provide not only essential physical scaffolds to maintain tissue structure but also various biochemical signals to modulate cellular function. ${ }^{[3-5]}$ Altering the fine balance of ECM signal is sufficient in the long run to induce breast cancer development and progression. Increased deposition of collagen and other ECM molecules enhances the cancer tissue stiffness. ${ }^{[6-9]}$

Collagens are the most abundant protein in the ECM. ${ }^{[10,11]}$ Collagen fibril has critical function for tumor cell growth, migration and metastasis. ${ }^{[12-14]}$ Other ECM components, such as hyaluronan, TNC, and periostin (POSTN), are also highly expressed in metastatic tumor and play important roles in tumor metastasis niche. ${ }^{[8,15-18]}$

Fibroblasts are considered the major source for ECM in both normal and malignant tissue. ${ }^{[19]}$ Surprisingly, recent studies showed that cancer cells also produce a significant quantity of ECM protein during cancer progression. ${ }^{[20,21]}$ Dr. Hynes's laboratory, utilizing an elegant proteomic experiment, demonstrated that ECM molecules in cancer tissue are deposited by both cancer cells and stromal cells. ${ }^{[20,21]}$ ECM proteins, such as laminin 5, hyaluronan, and TNC, are highly expressed in invasive cancer cells. ${ }^{[22-27]}$ Gene expression analysis has identified that ECM protein genes are upregulated in drug-resistant cancer cells. ${ }^{[28]}$ Collagen modification enzymes, including prolyl-4-hydroxylase $(\mathrm{P} 4 \mathrm{H})$, lysylhydroxylase (PLOD), and lysyl oxidase (LOX), as well as molecular chaperone heat shock protein 47 (HSP47), are highly expressed in cancer cells and are associated with tumor metastasis. ${ }^{[29-33]}$

This review summarizes recent findings about ECM microenvironment in solid tumor. The primary focus is on the role of cancer cells in ECM synthesis and the function of cancer cell-derived ECM in tumor progression.

\section{THE EXTRACELLULAR MATRIX}

ECM can be classified into two groups: the interstitial matrix and the basement membrane. ${ }^{[34]}$ Basement membranes are thin layers of ECM that form the supporting structure under epithelial and endothelial cells. ${ }^{[35]}$ Basement membrane has a distinctive composition containing type IV collagen, laminins, entactins, and proteoglycans. ${ }^{[7,36]}$ The interstitial matrix, which is primarily produced by stromal cells, fills in the interstitial space between cells. The interstitial matrix is rich in types I, III, V, VI, VII, and XII collagens, as well as proteoglycans and various glycoproteins such as TNC and fibronectin. ${ }^{[37]}$

Collagen is the most abundant protein in vivo. Fortyfour collagen genes have been identified in the human genome; they generate at least 28 different types of collagen. From precursor procollagen to final collagen fibril, collagen synthesis process involves several important modification enzymes. ${ }^{[10,38]}$ Proline and lysine hydroxylation are well characterized modifications on procollagen, which are catalyzed by two different enzymes: $\mathrm{P} 4 \mathrm{H}$ and PLOD. Collagen $\mathrm{P} 4 \mathrm{H}$ catalyzes the formation of 4-hydroxyproline, which is essential to the proper folding of newly synthesized procollagen chains. ${ }^{[3,40]}$ PLOD catalyzes the hydroxylation of lysyl residues in collagen-like peptides, which is critical for the formation of intermolecular crosslinks. ${ }^{[41,42]}$ LOX is enzyme-catalyzing formation of aldehydes from lysine residues in collagen after collagen secretion, which is required for collagen fibril formation. ${ }^{[43,44]}$ HSP47 is a molecular chaperone that promotes maturation of collagen molecules by inhibiting the aggregation of collagen in endoplasmic reticulum (ER). ${ }^{[45-47]}$ The expression of collagen-modification enzymes and molecular chaperone is often associated with increased collagen deposition in cancer tissue. ${ }^{[30-33,48-51]}$ Enhanced enzyme activities are often associated with increased collagen deposition in cancer tissue.

\section{ECM PLAYS IMPORTANT ROLES IN TUMOR PROGRESSION}

ECM is a major component of tumor microenvironment and plays critical roles in cancer development and progression. Increased ECM proteins deposition and crosslink provide necessary biochemical and biophysical cues to promote cancer cell proliferation, migration, and invasion. ${ }^{[12,52-54]}$ Laminin-322 is specifically localized in the dense fibrotic zone around invasive ductal carcinoma, providing a specialized microenvironment for guiding tumor invasion. ${ }^{[52]}$ Gamma 2 chain of laminin 5 (laminin 5 y2) is highly expressed in invasive mammary, colon, melanoma, and sarcoma cancer cells. Laminin 5 plays a role in establishing focal adhesions of cancer cells and contributes to cancer dissemination. ${ }^{[24-26]}$

ECM molecules, such as POSTN, fibronectin, and hyaluronan, are important components of the metastatic niche ${ }^{[7]}$ POSTN is a secreted extracellular matrix protein originally identified from mesenchymal cells. ${ }^{[8,16,17]}$ Deletion of POSTN has little effect on normal 
Table 1: Stroma cells and cancer cells-derived ECM proteins and ECM regulators

\begin{tabular}{|c|c|c|c|c|}
\hline & Stroma cells & References & Cancer cells & References \\
\hline \multirow[t]{18}{*}{ Collagens } & Collagen I & {$[20,21,66]$} & Collagen I & {$[20,21,53,65]$} \\
\hline & Collagen II & {$[20,21]$} & Collagen II & {$[20,21]$} \\
\hline & Collagen III & {$[20,21,66,67]$} & Collagen III & {$[20,21,53]$} \\
\hline & Collagen IV & {$[20,21]$} & Collagen IV & {$[20,21,28,65,68]$} \\
\hline & Collagen V & {$[20,21,53,66,67]$} & Collagen V & {$[20,21,53,63]$} \\
\hline & Collagen VI & {$[20,21,66]$} & Collagen VI & {$[20,21,28,53,68]$} \\
\hline & Collagen VII & {$[21]$} & Collagen VII & {$[20,21,68]$} \\
\hline & Collagen $\mathrm{X}$ & {$[20,21,66]$} & Collagen VIII & {$[20,53,63]$} \\
\hline & Collagen XI & {$[20,21,66]$} & Collagen IX & {$[20,68]$} \\
\hline & Collagen XII & [20] & Collagen $\mathrm{X}$ & {$[20,21,53,63]$} \\
\hline & Collagen XIV & {$[20,21,66]$} & Collagen XI & {$[20,21,53,63,68]$} \\
\hline & Collagen XV & {$[20,21]$} & Collagen XII & {$[20,21,31,63,65]$} \\
\hline & Collagen XVI & [20] & Collagen XV & {$[20,21,65,68]$} \\
\hline & Collagen XVIII & {$[20,21]$} & Collagen XVI & {$[20,21,28,65]$} \\
\hline & Collagen XVIIII & [21] & Collagen XVIII & {$[20,21,65]$} \\
\hline & Collagen XXIV & {$[20,21]$} & Collagen XIX & {$[20,21]$} \\
\hline & \multirow[t]{2}{*}{ Collagen XXVIII } & \multirow[t]{2}{*}{ [20] } & Collagen XXII & {$[20,21,63]$} \\
\hline & & & Collagen XXIV & {$[20,21,68]$} \\
\hline \multirow[t]{19}{*}{ Other ECM glycoproteins } & Fibrinogen & {$[20,21]$} & Laminin $\alpha 4$ & {$[20,21,28,65]$} \\
\hline & Dermatopontin & {$[20,21]$} & Laminin $\beta 1$ & {$[20,21,28,65,68]$} \\
\hline & Elastin & {$[20,21]$} & Laminin $\beta 2$ & {$[20,68]$} \\
\hline & Fibronectin1 & {$[20,21,66]$} & Laminin $\gamma 2$ & {$[20,21,66,68]$} \\
\hline & Laminin $\alpha 2$ & {$[20,67]$} & Fibronectin1 & {$[20,21,28,65,68]$} \\
\hline & Laminin $\beta 2$ & {$[20,21]$} & Elastin & {$[20,21]$} \\
\hline & Nidogen-1 & {$[20,67]$} & LTBP1 & {$[20,21,68]$} \\
\hline & Nidogen-2 & {$[21,66]$} & LTBP4 & {$[20,21]$} \\
\hline & ECM 1 & [21] & Nidogen-1 & {$[20,21]$} \\
\hline & Fibulin 2 & {$[20,21]$} & Nidogen-2 & {$[20,21]$} \\
\hline & LTBP2 & {$[20,21]$} & ECM 1 & {$[20,21,28,68]$} \\
\hline & Tenascin N & [20] & Peroxidasin & {$[20,21]$} \\
\hline & EMILIN2 & {$[20,21,66]$} & TINAGL1 & {$[20,21]$} \\
\hline & TNC & {$[20,66,67]$} & TNC & {$[20,21,66]$} \\
\hline & POSTN & {$[21,66]$} & Hyaluronan & [20] \\
\hline & Hyaluronan & [21] & Thrombospondin-1 & {$[20,21]$} \\
\hline & Thrombospondin-1 & [20] & SPARC & {$[20,53,65,68]$} \\
\hline & SPARC & {$[21,66,68]$} & & \\
\hline & Vitronectin & {$[20,21]$} & & \\
\hline \multirow[t]{3}{*}{ Proteoglycan } & Asporin & {$[20,21]$} & Biglycan & {$[20,21,28]$} \\
\hline & Biglycan & {$[20,66]$} & HAPLN1 & {$[20,65]$} \\
\hline & Decorin & {$[20,21,67]$} & Decorin & {$[20,21,53,65,68]$} \\
\hline
\end{tabular}

Continued... 


\begin{tabular}{lllll}
\hline & Stroma cells & References & Cancer cells & References \\
\hline ECM regulators & Cathepsin B & {$[20,21]$} & Cathepsin B & {$[20]$} \\
& ITIH1 & {$[20,21]$} & Osteonectin & {$[20,68]$} \\
& ITIH2 & {$[20,21]$} & P4HA1 & {$[20,21]$} \\
& Plasminogen & {$[20,21]$} & PLOD1 & {$[20,21,30]$} \\
P4HA1 & {$[50]$} & PLOD2 $]$ & {$[20,21]$} \\
P4HA2 & {$[50]$} & PLOD3 & {$[20,21,65]$} \\
PLOD2 & {$[50]$} & {$[20,21]$} & LOX & {$[20,21]$} \\
PLOD3 & {$[20,21]$} & LOXL2 & {$[20,21,33]$} \\
HSP50 & {$[21]$} & LOXL4 & {$[20]$} \\
LOXL1 & {$[20,21,66]$} & HSP50 & {$[20,21]$} \\
& TGF 31 & {$[21]$} & S100-A13 & {$[20,21]$} \\
& S100-A9 & S100-A4 & {$[20,21,65]$}
\end{tabular}

ECM1: extracellular matrix protein 1; EMILIN2: elastin microfibril interfacer 2; LTBP1: latent transforming growth factor beta binding protein 1; LTBP2: latent transforming growth factor beta binding protein 2; LTBP4: latent transforming growth factor beta binding protein 4; ITIH1: inter-alpha-trypsin inhibitor heavy chain H1; TINAGL1: tubulointerstitial nephritis antigen-like 1; HAPLN1: hyaluronan and proteoglycan link protein 1

tissue development and primary tumor growth, but it significantly suppresses breast cancer metastasis. ${ }^{[8,17]}$ POSTN promotes cancer stem cell maintenance and lung metastasis by enhancing the WNT signaling pathway. ${ }^{[8,17]}$ Fibronectin, a marker of epithelialmesenchymal transition, enhances cancer metastasis through Src kinase and extracellular signal-regulated kinase/mitogen-activated protein kinase pathway. ${ }^{[55]}$ Hyaluronan expression is upregulated in breast cancer, lung cancer, pancreatic cancer, melanoma cancer, and myeloma cancer. ${ }^{[22,23,27]}$ Upregulation of hyaluronan is also associated with tumor progression and poor prognosis. ${ }^{[15,56,57]}$ Hyaluronan receptor CD44 promotes survival of disseminated cancer cells during metastasis. ${ }^{[58]}$ TNC is an oligomeric glycoprotein composed of individual polypeptides with molecular weights ranging from $180 \mathrm{kDa}$ to $300 \mathrm{kDa}$. Expression of TNC in breast tumor is associated with lung metastasis. ${ }^{[8,16,18]}$ Recent studies reveal that TNC is a critical component of metastatic niche and supports survival of disseminated cancer cells at secondary organs. ${ }^{[8,16,18]}$

Collagen is the major structural ECM protein in tumor tissue. It has been shown that women with dense breasts have a four- to six-fold increased risk of developing breast cancer, and the dense breast correlates with increased collagen deposition and crosslink. In addition, the crosslinked and orientated collagen in cancer tissue is a reliable marker associated with poor survival, regardless of tumor grade and size, tumor subtype, ER or PR status, and node status. ${ }^{[12,59]}$
The abnormal deposition of collagen in tumor stroma promotes cancer progression. Increased collagen $\mathrm{VI}$ deposition stimulates cancer cell proliferation. ${ }^{[59-61]}$ Col5A2 and Col11A1 are highly expressed in invasive ductal carcinoma compared to ductal carcinoma in situ. Both of them are involved in triggering cancer cells to disseminate. ${ }^{[62,63]}$

Collagen production and deposition is regulated by a variety of enzymes, including P4Hs, PLODs, and LOXs. Collagen deposition is regulated by hypoxia in tumor tissue. ${ }^{[47,48,61]}$ Collagen modification enzymes, P4Hs, PLOD, and LOX, are activated by HIF-1 $\alpha$ in cancer cells. ${ }^{[27,28,40,48]}$ Expression of collagen $\mathrm{P} 4 \mathrm{H}$ is significantly upregulated in breast cancer. Knockdown of P4HA inhibits mammary tumor growth and metastasis to lungs, and decreased P4HA activity depresses cancer cell alignment along collagen fibers. ${ }^{[31,32,50]}$ PLOD2 expression is also associated with increased risk of mortality in breast cancer patient. PLOD2 is critical for breast cancer cell metastasis to lymph nodes and lungs because it increases fibril collagen formation and increases tumor stiffness. ${ }^{[30]}$ In sarcoma cancer, inhibition of PLOD enzymatic activity suppresses metastases. ${ }^{[64]}$ Secretion of LOX by metastatic breast cancer cells is upregulated in metastasis niche. Increased activity of LOX recruits bone marrowderived cells (BMDCs) to metastasis niche. BMDCs are important in creating a microenvironment for metastatic cancer-cell invasion and growth. ${ }^{[43]}$ Increased LOX expression results in increased ECM stiffening, which is essential for cancer cell expansion. ${ }^{[7]}$ Inhibition 


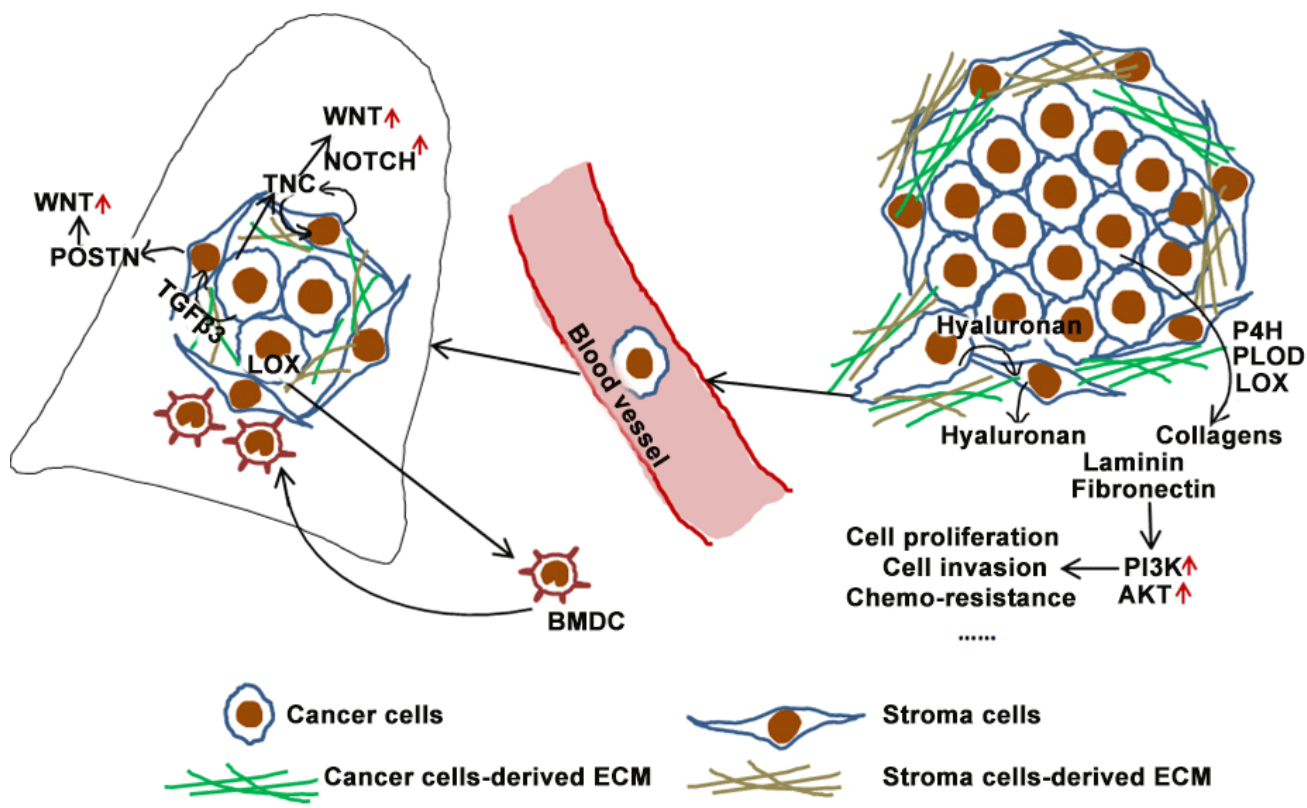

Figure 1: Stroma cell-derived extracellular matrix (ECM) and cancer cell-derived ECM collectively support cancer cell proliferation, invasion, and metastasis. ECM: extracellular matrix; BMDC: bone marrow-derived cells; PLOD: lysyl-hydroxylase; LOX: lysyl oxidase

LOX activation reduces collagen fibril formation and ECM stiffness, which depresses focal adhesions and PI3K activity, and consequently suppresses cancer cell invasion. ${ }^{[54]}$ These results indicate that collagen modification enzymes P4Hs, PLODs, and LOXs play critical roles in cancer cell metastasis.

\section{CANCER CELLS ARE CRITICAL SOURCES OF TUMOR ECM}

The cellular components of tumor stroma include fibroblasts, endothelial cells, fat cells, and immune cells. It has been shown that cancer-associated fibroblasts produce and regulate the ECM remodeling in cancer tissue, and the roles of cancer cells in ECM deposition have not been appreciated until recently. Dr. Hynes's laboratory investigated matrisome (ECM and ECM-associated proteins) in colon tumor tissues, lung tumor tissues, and human breast cancer tissue. ${ }^{[20,21]}$ They found that ECM components in tumor matrix are derived from cancer cells and stromal cells, and many of them are only expressed by cancer cells, including Col19A1, Col22A1, Col7A1, LAMA4, LAMB1, LTBP1, LTBP3, LTBP4, TINAGL1, and ECM regulators galectin 1 (LGALS1) and PLOD1..20,21] Gene expression analysis of drug-resistant breast cancer cells has found that $25 \mathrm{ECM}$ components' genes (including collagen, fibronectin, syndecan, and laminin) and integrin ligands are upregulated in drug-resistant breast cancer cells. ${ }^{[28]}$ Gene expression analysis of drug-resistant ovarian cancer cells also discovered that molecules in ECM networks, including COL3A1, COL5A2, COL15A1, and LOX, among others, are very significantly upregulated. ${ }^{[65]}$ Gene expression profile studies from other labs also reveal that expression of genes involved in synthesis and organization of ECM are upregulated in the epithelium of invasive cancer cells. ${ }^{[53,63,66-68]}$

LAMC2 (gamma 2 chain gene of laminin 5) is highly expressed in invasive cancer cells in mammary, colon, melanoma and sarcoma tumora. ${ }^{[24-26,69]}$ Hyaluronan synthesis is increased in a variety types of cancer cells, including breast tumor, melanoma tumor, and myeloma tumor. ${ }^{[22,23,27]}$ Thrombospondin-1 is expressed in the stroma and cancer cells. ${ }^{[70]} \mathrm{TNC}$, a key metastatic niche molecule required for the metastasis initiation, is also expressed in breast tumor cells and stroma cells..$^{[8,16,18]}$ Collagens are mainly synthesized by cancer-associated fibroblasts in breast cancer, but cancer cells are also an important source of the collagen. ${ }^{[63]}$ In addition, the expression of collagen synthesis regulating enzymes $\mathrm{P} 4 \mathrm{H}$ and PLOD is induced by the HIF-1 pathway in cancer cells. ${ }^{[30,31,51,64]}$ We have summarized ECM proteins and ECM-related enzymes derived from the stroma cells and cancer cells in Table 1. This evidence clearly shows that cancer cells are a major source of tumor ECM.

\section{CANCER CELL-DERIVED ECM IN CANCER PROGRESSION AND METASTASIS}

ECM deposited by cancer cells is crucial for cancer progression and metastasis. It has been shown that inhibition of LOX expression in cancer cell represses cell adhesion, migration, and invasion. ${ }^{[29,71]}$ Hyaluronan 
deposited by cancer cells promotes cell proliferation, migration, invasion, metastasis, multidrug resistance, and tumor-associated angiogenesis. ${ }^{[15,56,57]}$ TNC that is derived from disseminated tumor cells promotes lung metastasis by enhancing NOTCH and WNT signaling pathways [Figure 1]. ${ }^{[8,16,18]}$ In addition, cancer cell-derived ECM proteins (fibronectin, collagen, and laminin) protect cancer cells from chemotherapyinduced apoptosis via activation of the PI3k/AKT pathway [Figure 1]. ${ }^{[72,73]}$

Cancer cell-derived ECM proteins mediate the cancer cell-stromal cell crosstalk. Hyaluronan production by stroma fibroblasts is stimulated by factors secreted by cancer cells. ${ }^{[7,75]}$ Metastatic niche molecule POSTN is secreted by stoma fibroblasts of breast tumor under stimulation from the tumor cells that are produced TGF- $\beta 3$ [Figure 1]. ${ }^{[8,16-18]}$ Cancer cells also remotely recruit stromal cells to create a premetastatic niche before metastasis. Cancer cells-derived TNC initiates cancer cell metastasis, and then it stimulates stroma cell-derived TNC synthesis. Ablation of TNC expression in cancer cells at an early time in the metastatic process inhibits the outgrowth of lung metastases. Interestingly, inhibition TNC expression in cancer cells at a late stage of metastasis does not affect micrometastases expanding to macrometastases, because metastatic cancer cells have already induced TNC expression in stromal cells to promote tumor growth. ${ }^{[8,16,18]}$ These results indicate that cancer cell-derived ECM molecules are critical regulators of the initiation of metastasis outgrowth through activating the stromal cells in the secondary organs [Figure 1].

\section{CONCLUSION}

In summary, tumor cells play critical roles in ECM deposition and remodeling during cancer development and progression. Accumulated evidence demonstrates that ECM molecules deposited by cancer cells promote cancer progression by enhancing cell survival and proliferation. However, it largely remains to be determined how cancer cell-derived ECM is regulated and how those ECM proteins function in tumor microenvironment remodeling. Answering those questions is critical for developing potential cancer treatment strategies by targeting the cancer cellderived ECM and ECM-related enzymes.

\section{Financial support and sponsorship}

This study was supported by start-up funding from Markey Cancer Center and funding support from United States Department of Defense (W81XWH-15-1-0052 to R.X.).

\section{Conflicts of interest}

There are no conflicts of interest.

\section{Patient consent}

No patient involved.

\section{Ethics approval}

This article does not contain any studies with human participants or animals.

\section{REFERENCES}

1. Bissell MJ, Hines WC. Why don't we get more cancer? A proposed role of the microenvironment in restraining cancer progression. Nat Med 2011;17:320-9.

2. Zhu J, Xiong G, Trinkle C, Xu R. Integrated extracellular matrix signaling in mammary gland development and breast cancer progression. Histol Histopathol 2014;29:1083-92.

3. Spencer VA, Xu R, Bissell MJ. Extracellular matrix, nuclear and chromatin structure, and gene expression in normal tissues and malignant tumors: a work in progress. Adv Cancer Res 2007; 97:275-94.

4. $\mathrm{Xu} \mathrm{R}$, Boudreau A, Bissell MJ. Tissue architecture and function: dynamic reciprocity via extra- and intra-cellular matrices. Cancer Metastasis Re 2009;28:167-76.

5. Xu R, Nelson CM, Muschler JL, Veiseh M, Vonderhaar BK, Bissell MJ. Sustained activation of STAT5 is essential for chromatin remodeling and maintenance of mammary-specific function. $J$ Cell Biol 2009; 184:57-66.

6. Cox TR, Erler JT. Remodeling and homeostasis of the extracellular matrix: implications for fibrotic diseases and cancer. Dis Model Mech 2011;4:165-78.

7. Lu P, Weaver VM, Werb Z. The extracellular matrix: a dynamic niche in cancer progression. J Cell Biol 2012;196:395-406.

8. Oskarsson T, Massague J. Extracellular matrix players in metastatic niches. EMBO J 2012;31:254-6.

9. Pickup MW, Mouw JK, Weaver VM. The extracellular matrix modulates the hallmarks of cancer. EMBO Rep 2014;15:1243-53.

10. Canty EG, Kadler KE. Procollagen trafficking, processing and fibrillogenesis. J Cell Sci 2005;118:1341-53.

11. Lochter A, Bissell MJ. Involvement of extracellular matrix constituents in breast cancer. Semin Cancer Biol 1995;6:165-73.

12. Provenzano PP, Eliceiri KW, Campbell JM, Inman DR, White JG, Keely PJ. Collagen reorganization at the tumor-stromal interface facilitates local invasion. BMC Med 2006 26;4:38.

13. Provenzano PP, Inman DR, Eliceiri KW, Knittel JG, Yan L, Rueden CT, White JG, Keely PJ. Collagen density promotes mammary tumor initiation and progression. BMC Med 2008;6:11.

14. Aguilera KY, Rivera LB, Hur H, Carbon JG, Toombs JE, Goldstein CD, Dellinger MT, Castrillon DH, Brekken RA. Collagen signaling enhances tumor progression after anti-VEGF therapy in a murine model of pancreatic ductal adenocarcinoma. Cancer Res 2014;74:1032-44.

15. Götte M, Yip GW. Heparanase, hyaluronan, and CD44 in cancers: a breast carcinoma perspective. Cancer Res 2006;66:10233-7.

16. Kii I, Nishiyama T, Li M, Matsumoto K, Saito M, Amizuka N, Kudo A. Incorporation of tenascin-C into the extracellular matrix by periostin underlies an extracellular meshwork architecture. $J$ Biol Chem 2010;285:2028-39.

17. Malanchi I, Santamaria-Martinez A, Susanto E, Peng H, Lehr HA, Delaloye JF, Huelsken J. Interactions between cancer stem cells and their niche govern metastatic colonization. Nature 2012;481:85-9.

18. Oskarsson T, Acharyya S, Zhang XH, Vanharanta S, Tavazoie SF, 
Morris PG, Downey RJ, Manova-Todorova K, Brogi E, Massague J. Breast cancer cells produce tenascin $\mathrm{C}$ as a metastatic niche component to colonize the lungs. Nat Med 2011;17:867-74.

19. Karagiannis GS, Poutahidis T, Erdman SE, Kirsch R, Riddell RH, Diamandis EP. Cancer-associated fibroblasts drive the progression of metastasis through both paracrine and mechanical pressure on cancer tissue. Mol Cancer Res 2012;10:1403-18.

20. Naba A, Clauser KR, Hoersch S, Liu H, Carr SA, Hynes RO. The matrisome: in silico definition and in vivo characterization by proteomics of normal and tumor extracellular matrices. Mol Cell Proteomics 2012;11: M111.014647.

21. Naba A, Clauser KR, Lamar JM, Carr SA, Hynes RO. Extracellular matrix signatures of human mammary carcinoma identify novel metastasis promoters. Elife 2014;3:e01308.

22. Calabro A, Oken MM, Hascall VC, Masellis AM. Characterization of hyaluronan synthase expression and hyaluronan synthesis in bone marrow mesenchymal progenitor cells: predominant expression of HAS1 mRNA and up-regulated hyaluronan synthesis in bone marrow cells derived from multiple myeloma patients. Blood 2002;100:2578-85.

23. Kimata K, Honma Y, Okayama M, Oguri K, Hozumi M, Suzuki $\mathrm{S}$. Increased synthesis of hyaluronic acid by mouse mammary carcinoma cell variants with high metastatic potential. Cancer Res 1983;43:1347-54.

24. Patarroyo M, Tryggvason K, Virtanen I. Laminin isoforms in tumor invasion, angiogenesis and metastasis. Semin Cancer Biol 2002;12:197-207.

25. Pyke C, Romer J, Kallunki P, Lund LR, Ralfkiaer E, Dano $\mathrm{K}$, Tryggvason $\mathrm{K}$. The gamma 2 chain of kalinin/laminin 5 is preferentially expressed in invading malignant cells in human cancers. Am J Pathol 1994;145:782-91.

26. Seftor RE, Seftor EA, Koshikawa N, Meltzer PS, Gardner LM, Bilban M, Stetler-Stevenson WG, Quaranta V, Hendrix MJ. Cooperative interactions of laminin 5 gamma2 chain, matrix metalloproteinase-2, and membrane type-1-matrix/metalloproteinase are required for mimicry of embryonic vasculogenesis by aggressive melanoma. Cancer Res 2001;61:6322-7.

27. Zhang L, Underhill CB, Chen L. Hyaluronan on the surface of tumor cells is correlated with metastatic behavior. Cancer Res 1995;55:428-33.

28. Iseri OD, Kars MD, Arpaci F, Gunduz U. Gene expression analysis of drug-resistant MCF-7 cells: implications for relation to extracellular matrix proteins. Cancer Chemother Pharmacol 2010;65:447-55.

29. Erler JT, Bennewith KL, Nicolau M, Dornhofer N, Kong C, Le QT, Chi JT, Jeffrey SS, Giaccia AJ. Lysyl oxidase is essential for hypoxiainduced metastasis. Nature 2006;440:1222-6.

30. Gilkes DM, Bajpai S, Wong CC, Chaturvedi P, Hubbi ME, Wirtz D, Semenza GL. Procollagen lysyl hydroxylase 2 is essential for hypoxia-induced breast cancer metastasis. Mol Cancer Res 2013;11:456-66.

31. Gilkes DM, Chaturvedi P, Bajpai S, Wong CC, Wei H, Pitcairn S, Hubbi ME, Wirtz D, Semenza GL. Collagen prolyl hydroxylases are essential for breast cancer metastasis. Cancer Res 2013;73:3285-96.

32. Xiong G, Deng L, Zhu J, Rychahou PG, Xu R. Prolyl-4-hydroxylase alpha subunit 2 promotes breast cancer progression and metastasis by regulating collagen deposition. BMC cancer 2014;14:1.

33. Zhu J, Xiong G, Fu H, Evers BM, Zhou BP, Xu R. Chaperone Hsp47 Drives Malignant Growth and Invasion by Modulating an ECM Gene Network. Cancer Res 2015;75:1580-91.

34. Guo W, Giancotti FG. Integrin signalling during tumour progression. Nat Rev Mol Cell Biol 2004;5:816-26.

35. Paulsson M. Basement membrane proteins: structure, assembly, and cellular interactions. Crit Rev Biochem Mol Biol 1992;27:93-127.
36. Laurila P, Leivo I. Basement membrane and interstitial matrix components form separate matrices in heterokaryons of PYS-2 cells and fibroblasts. J Cell Sci 1993;104:59-68.

37. Egeblad M, Rasch MG, Weaver VM. Dynamic interplay between the collagen scaffold and tumor evolution. Curr Opin Cell Biol 2010;22:697-706.

38. Knott L, Bailey AJ. Collagen cross-links in mineralizing tissues: a review of their chemistry, function, and clinical relevance. Bone 1998;22:181-7.

39. Gorres KL, Raines RT. Prolyl 4-hydroxylase. Crit Rev Biochem Mol Biol 2010;45:106-24.

40. Kukkola L, Hieta R, Kivirikko KI, Myllyharju J. Identification and characterization of a third human, rat, and mouse collagen prolyl 4-hydroxylase isoenzyme. J Biol Chem 2003;278:47685-93.

41. Valtavaara M, Szpirer C, Szpirer J, Myllyla R. Primary structure, tissue distribution, and chromosomal localization of a novel isoform of lysyl hydroxylase (lysyl hydroxylase 3). J Biol Chem 1998;273:12881-6.

42. van der Slot AJ, Zuurmond AM, Bardoel AF, Wijmenga C, Pruijs HE, Sillence DO, Brinckmann J, Abraham DJ, Black CM, Verzijl N, DeGroot J, Hanemaaijer R, TeKoppele JM, Huizinga TW, Bank RA. Identification of PLOD2 as telopeptide lysyl hydroxylase, an important enzyme in fibrosis. J Biol Chem 2003;278:40967-72.

43. Erler JT, Bennewith KL, Cox TR, Lang G, Bird D, Koong A, Le QT, Giaccia AJ. Hypoxia-induced lysyl oxidase is a critical mediator of bone marrow cell recruitment to form the premetastatic niche. Cancer cell 2009;15:35-44.

44. Kagan HM, Li W. Lysyl oxidase: properties, specificity, and biological roles inside and outside of the cell. $J$ Cell Biochem 2003;88:660-72.

45. Koide T, Aso A, Yorihuzi T, Nagata K. Conformational requirements of collagenous peptides for recognition by the chaperone protein HSP47. J Biol Chem 2000;275:27957-63.

46. Nagata K. Hsp47: a collagen-specific molecular chaperone. Trends Biochem Sci 1996;21:22-6.

47. Tasab M, Jenkinson L, Bulleid NJ. Sequence-specific recognition of collagen triple helices by the collagen-specific molecular chaperone HSP47. J Biol Chem 2002;277:35007-12.

48. Bignon M, Pichol-Thievend C, Hardouin J, Malbouyres M, Brechot N, Nasciutti L, Barret A, Teillon J, Guillon E, Etienne E, Caron M, Joubert-Caron R, Monnot C, Ruggiero F, Muller L, Germain S. Lysyl oxidase-like protein-2 regulates sprouting angiogenesis and type IV collagen assembly in the endothelial basement membrane. Blood 2011;118:3979-89.

49. Cox TR, Bird D, Baker AM, Barker HE, Ho MW, Lang G, Erler JT. LOX-mediated collagen crosslinking is responsible for fibrosisenhanced metastasis. Cancer Res 2013;73:1721-32.

50. Gilkes DM, Bajpai S, Chaturvedi P, Wirtz D, Semenza GL. Hypoxiainducible factor 1 (HIF-1) promotes extracellular matrix remodeling under hypoxic conditions by inducing P4HA1, P4HA2, and PLOD2 expression in fibroblasts. J Biol Chem 2013;288:10819-29.

51. Gilkes DM, Semenza GL, Wirtz D. Hypoxia and the extracellular matrix: drivers of tumour metastasis. Nat Rev Cancer 2014;14:430-9.

52. Kim BG, An HJ, Kang S, Choi YP, Gao MQ, Park H, Cho NH. Laminin-332-rich tumor microenvironment for tumor invasion in the interface zone of breast cancer. Am J Pathol 2011;178:373-81.

53. Lee S, Stewart S, Nagtegaal I, Luo J, Wu Y, Colditz G, Medina D, Allred DC. Differentially expressed genes regulating the progression of ductal carcinoma in situ to invasive breast cancer. Cancer Res 2012;72:4574-86.

54. Levental KR, Yu H, Kass L, Lakins JN, Egeblad M, Erler JT, Fong SF, Csiszar K, Giaccia A, Weninger W, Yamauchi M, Gasser DL, Weaver VM. Matrix crosslinking forces tumor progression by 
enhancing integrin signaling. Cell 2009;139:891-906.

55. Park J, Schwarzbauer JE. Mammary epithelial cell interactions with fibronectin stimulate epithelial-mesenchymal transition. Oncogene 2014;33:1649-57.

56. Cook AC, Chambers AF, Turley EA, Tuck AB. Osteopontin induction of hyaluronan synthase 2 expression promotes breast cancer malignancy. J Biol Chem 2006;281:24381-9.

57. Toole BP. Hyaluronan: from extracellular glue to pericellular cue. Nat Rev Cancer 2004;4:528-39.

58. Yu Q, Toole BP, Stamenkovic I. Induction of apoptosis of metastatic mammary carcinoma cells in vivo by disruption of tumor cell surface CD44 function. J Exp Med 1997;186:1985-96.

59. Conklin MW, Eickhoff JC, Riching KM, Pehlke CA, Eliceiri KW, Provenzano PP, Friedl A, Keely PJ. Aligned collagen is a prognostic signature for survival in human breast carcinoma. Am J Pathol 2011;178:1221-32.

60. Iyengar P, Espina V, Williams TW, Lin Y, Berry D, Jelicks LA, Lee H, Temple K, Graves R, Pollard J, Chopra N, Russell RG, Sasisekharan R, Trock BJ, Lippman M, Calvert VS, Petricoin EF 3rd, Liotta L, Dadachova E, Pestell RG, Lisanti MP, Bonaldo P, Scherer PE. Adipocyte-derived collagen VI affects early mammary tumor progression in vivo, demonstrating a critical interaction in the tumor/ stroma microenvironment. J Clin Invest 2005;115:1163-76.

61. Park J, Scherer PE. Adipocyte-derived endotrophin promotes malignant tumor progression. J Clin Invest 2012;122:4243-56.

62. Barsky SH, Rao CN, Grotendorst GR, Liotta LA. Increased content of Type V Collagen in desmoplasia of human breast carcinoma. Am J Pathol 1982;108:276-83.

63. Vargas AC, McCart Reed AE, Waddell N, Lane A, Reid LE, Smart CE, Cocciardi S, da Silva L, Song S, Chenevix-Trench G, Simpson PT, Lakhani SR. Gene expression profiling of tumour epithelial and stromal compartments during breast cancer progression. Breast Cancer Res Treat 2012;135:153-65.

64. Eisinger-Mathason TS, Zhang M, Qiu Q, Skuli N, Nakazawa MS, Karakasheva T, Mucaj V, Shay JE, Stangenberg L, Sadri N, Puré E, Yoon SS, Kirsch DG, Simon MC. Hypoxia-dependent modification of collagen networks promotes sarcoma metastasis. Cancer Discov 2013;3:1190-205.

65. Januchowski R, Zawierucha P, Rucinski M, Nowicki M, Zabel M. Extracellular matrix proteins expression profiling in chemoresistant variants of the A2780 ovarian cancer cell line. Biomed Res Int 2014;2014:365867.
66. Casey T, Bond J, Tighe S, Hunter T, Lintault L, Patel O, Eneman J, Crocker A, White J, Tessitore J, Stanley M, Harlow S, Weaver D, Muss H, Plaut K. Molecular signatures suggest a major role for stromal cells in development of invasive breast cancer. Breast Cancer Res Treat 2009;114:47-62.

67. Thomas SS, Makar KW, Li L, Zheng Y, Yang P, Levy L, Rudolph RY, Lampe PD, Yan M, Markowitz SD, Bigler J, Lampe JW, Potter JD. Tissue-specific patterns of gene expression in the epithelium and stroma of normal colon in healthy individuals in an aspirin intervention trial. BMC Med Genet 2015;16:18.

68. Ting DT, Wittner BS, Ligorio M, Vincent Jordan N, Shah AM Miyamoto DT, Aceto N, Bersani F, Brannigan BW, Xega K, Ciciliano JC, Zhu H, MacKenzie OC, Trautwein J, Arora KS, Shahid M, Ellis HL, Qu N, Bardeesy N, Rivera MN, Deshpande V, Ferrone CR, Kapur R, Ramaswamy S, Shioda T, Toner M, Maheswaran S, Haber DA. Single-cell RNA sequencing identifies extracellular matrix gene expression by pancreatic circulating tumor cells. Cell Rep 2014;8:1905-18.

69. Kostourou V, Papalazarou V. Non-collagenous ECM proteins in blood vessel morphogenesis and cancer. Biochim Biophys Acta 2014;1840:2403-13

70. Ioachim E, Damala K, Tsanou E, Briasoulis E, Papadiotis E, Mitselou A, Charhanti A, Doukas M, Lampri L, Arvanitis DL. Thrombospondin-1 expression in breast cancer: prognostic significance and association with p53 alterations, tumour angiogenesis and extracellular matrix components. Histol Histopathol 2012;27:209-16.

71. Bondareva A, Downey CM, Ayres F, Liu W, Boyd SK, Hallgrimsson B, Jirik FR. The lysyl oxidase inhibitor, beta-aminopropionitrile, diminishes the metastatic colonization potential of circulating breast cancer cells. PLoS One 2009;4:e5620.

72. Aoudjit F, Vuori K. Integrin signaling in cancer cell survival and chemoresistance. Chemother Res Pract 2012;2012:283181.

73. Hoshiba T, Tanaka M. Breast cancer cell behaviors on staged tumorigenesis-mimicking matrices derived from tumor cells at various malignant stages. Biochem Biophys Res Commun 2013;439:291-6.

74. Asplund T, Versnel MA, Laurent TC, Heldin P. Human mesothelioma cells produce factors that stimulate the production of hyaluronan by mesothelial cells and fibroblasts. Cancer Res 1993;53:388-92.

75. Knudson W, Biswas C, Toole BP. Interactions between human tumor cells and fibroblasts stimulate hyaluronate synthesis. Proc Natl Acad Sci U S A 1984;81:6767-71. 